\title{
Investigating Factors Affecting Poultry Farmers and Poultry Farms Towards Sustainable Development. A Case study of Poultry Association of Zambia Registered Poultry Farmers in Lusaka Province
}

\author{
Article by Namonze Chilala \\ PhD, Business Management, Texila American University, Zambia \\ E-mail: namonzechilala@yahoo.com
}

\begin{abstract}
This research is based on the study of factors affecting poultry farmers and farms in Lusaka Province Zambia. The economic value of poultry cannot be underestimated, they are highly contributing in gross domestic product and fast-growing industry providing large number of employment and animal food production in Zambia.

the researcher has seen a gap between farmer, farm and sustainable development. The future of poultry farming is not certain.

Available evidence has shown that there are a number of factors that affect poultry farmers and poultry farms in Zambia which has affected the poultry industry to continue growing.

However, the poultry has been having improvement in some areas such as production despite the negative internal and external factors that has been affecting the industry. As a result of this the researcher has opted to investigate the factors that are affecting poultry farmers and the factors affecting farms respectively. In order to understand the research question, the research is going to define the key words of the study. Then the factors affecting poultry and farms are given. Followed by the existing solutions for the problem and the best one will be outlined. Limitations and achievements with sustainable development to the study will discussed. The findings will add to the body of knowledge for other researchers. The findings will be used by researchers to build theories and models that relate the factors to the poultry industry. When the theories are formed will help to sustain the poultry farmer and farm to continue for our future generation to come.
\end{abstract}

Keywords: Factors, poultry farmers, poultry farms, Sustainable development, Poultry association of Zambia, Zambia.

\section{Introduction}

The poultry industry in Zambia contributes about 47 percent of the livestock gross domestic product. About 5 percent of the national gross product. It has created over and over 80,000 jobs. It is the fastest growing sub-sector about 20 percent in the past decade (about 8 percent reduction during 2016). The industry growth is driven mainly by the broiler and layer subsectors. Secondary production is still dominated by the smallholder farmers-accounting for 65 percent while 35 percent is by medium, larger, commercial and corporate. Poultry development has also driven the growth of the poultry feed subsector, soya beans and grains.

\section{Definition of keywords}

Factor - a factor is one of the things that affects an event, decision, or situation. (collinsdictionary.com) is a circumstance, fact, or influence that contributes to a result."

Poultry according to learner's definition is "birds (such as chickens and ducks) that are raised on farms for their eggs or meat" (merriam-webster,com)

Poultry farmer is "someone who raises domesticated birds such as geese, ducks, turkeys or chickens for the purpose of farming meat and eggs for sale and consumption. A poultry farmer typically raises a 
DOI: 10.21522/TIJMG.2015.SE.19.01.Art001

ISSN: $2520-310 \mathrm{X}$

single type of poultry, with more than half of the poultry farming industry raising chickens. A poultry farmer is a specialized type of farmer. Also known as: Turkey Farmer, Chicken Farmer, Duck farmer, Goose farmer. (www, sonaku.com). However, in this study, the researcher is going to focus at the chicken farmer.

Sustainable Development has been defined in many ways, but the most frequently quoted definition is our common future, also known as the Brundtland report:

"Sustainable development is development that meets the needs of the present without compromising the ability of future generations to meet their own needs."

Sustainability is the foundation for today's leading global framework for international cooperation-2030 Agenda for Sustainable Development Goals (SDGS).

\section{Poultry association of zambia and its role}

According to a presentation by poultry Association of Zambia on 26 April 2017, it stated that:

- This association was established in 2000 , with currently 7000 registered members out of the 30,000 potential farmers.

- foot prints in about 32 districts out of 110 districts.

- mouth piece for the poultry industry the poultry allied industry.

- Lobby's and advocates for conducive policies for poultry farmers.

- The association gathers critical poultry information significant for investment decision in the sector.

- It also provides technical information to farmers and other members allied to it.

\section{Zambia}

\section{Background of zambia}

Zambia is a landlocked country in Africa. It is situated on high plateau in south-central Africa and Zambia, landlocked country in Africa. It is situated on high plateau in south-central Africa and takes its name from the Zambezi river. Which drains all but a small northern part of the country. Large parts of the country are thinly populated. Much of population is concentrated in the country's most developed area known as the line of rail, which is served by the railway linking the copper belt with Lusaka the capital, and with the border town of Livingstone. 


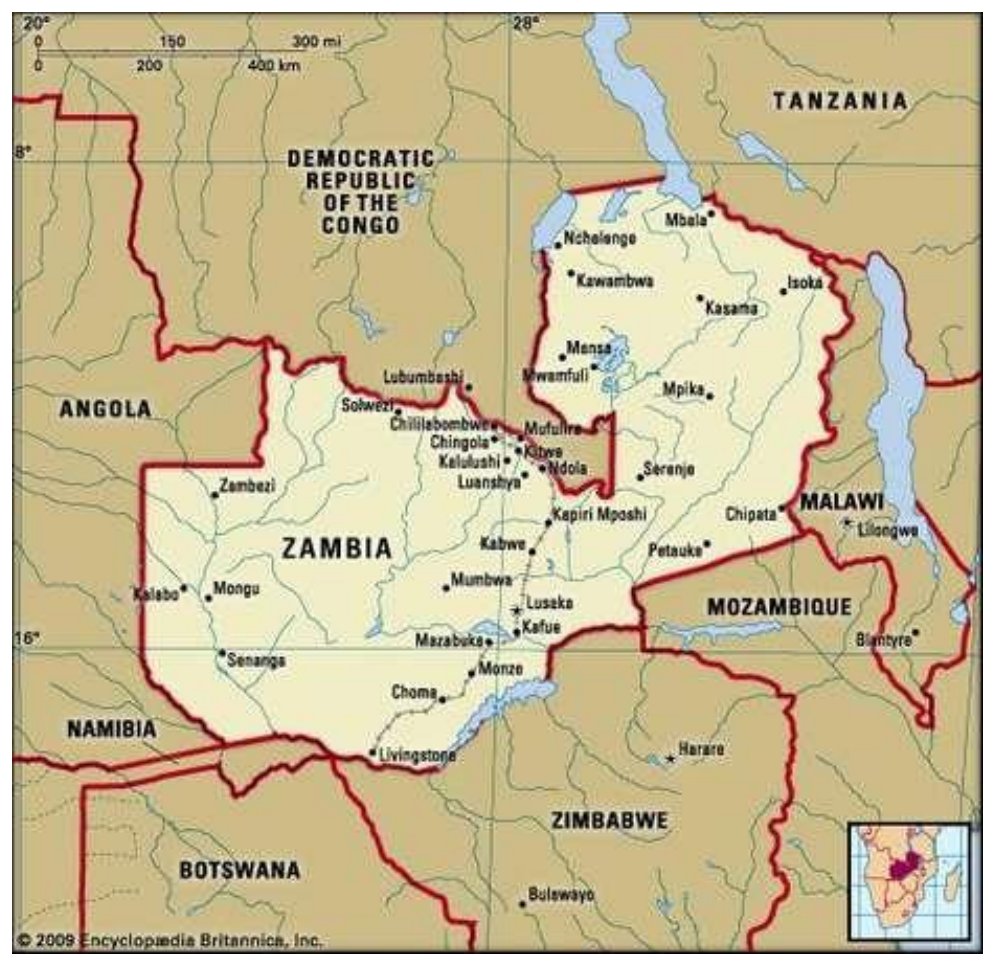

Figure 1. Map of Zambia

Source: Encyclopedia Britannica, Inc.

\section{What is sustainable development?}

Sustainable development is development that meets the needs of the present without compromising the ability of future generations to meet their own needs

\section{Background of poultry study}

There are many factors that have identified by the research. There are internal and external factors.

According to Mwape.N. (2017, p2) affirms that the poultry industry has recorded a sharp drop in egg production of 26 percent (while the broiler subsector fell by 4.8 percent during the economic trough experience in 2016. (Mwape 2017).

According to poultry Association of Zambia, in the egg subsector. 1.99 million chicks were produced last year compared to 2.34 million chicks were produced last year compared to 2.34 million in 2015 . The total volumes of chickens and eggs sold on the Zambian market dropped and also the selling prices for poultry products dropped. This situation was mainly due to the eroded purchasing power of customers. (IBID).

Production costs like feed, feed, fuel, equipment and other inputs went up, mushrooming of unregulated fees and levies emerging in different district councils that are adding cost to the industry. Avian influenza is a disease that poultry farmers are under intense threat due to the rate at which the disease is spreading. He called for enforcement of high-level bio-security and hygiene practices as a precautionary measure. (Sosala R.2017)

\section{Factors affecting poultry farmers}

The poultry sector in Zambia is the largest contribution to livestock GDP contribution about $42 \%$ PAP (2011) which is thus an important industry which needs to be harnessed and developed to international standards. Despite the fact that most layers and broilers are on commercial farms, the number of households that rely on poultry as their main source of income is significantly high amongst the small-scale producers 
DOI: 10.21522/TIJMG.2015.SE.19.01.Art001

ISSN: $2520-310 \mathrm{X}$

IAPRI (2011). This is the reason we have seen increased traders of both eggs and broilers on our local markets that product their flock under the backyard system. (Harad. C. L 2013).

Commercial farmers are usually integrated in Zambia as they produce for ready markets which are usually mega Supermarkets like Shoprite, spar and pick and pay under contracts. Commercial farmers go further in production as they process the birds by slaughtering them then packing them as assorted chickens as per requirement by the supermarkets. The same scenario applies for layers. The eggs cleaned and packed in branded trays then distributed to the supermarkets.

Some of the factors faced by poultry farmers according to Lungu (2011) are as follows:

Gender, Age, level of education, household size, farm gate price, marketing challenges, levels of management, production costs, market outlets and labours. (Lungu C.H 2011).

The increase in chicken feed is likely to push some poultry farmers out of business if there are no measures to reduce the impact (Mupeseni K. 2015).

Furthermore, Mupeseni continues to say that according to the poultry Association of Zambia. (PAZ). Says the rising costs of feed have left a lot of small and medium poultry farmers considering suspending their operations cost on feed now.

The rising cost of feed has resulted in most small and micro farmers who represent a significant number of the industry unable to meet their overhead costs of sustaining the operations. (Mbale Tryness 2018).

Due to the open market system in the country the price some farmers are considering suspending their farm operations with feed pegged as K275 for broiler starter feed. It has been predicted by industry players that if the present crisis is not addressed and the market forces do not control the situation, a lot more farmers may be forced out of the market, which may result in reduced supply of eggs and chickens (IBID).

Unregulated fees and levies by district councils which are increasing costs to the industry and making it uncompetitive. (IBID).

A commercial poultry farm and eggs production company may face challenges such as the economic downturn that can impact negatively on household spending, bad weather, cum natural disasters (draughts, epidemics) unfavorable government policies and the arrival of a competitor (a commercial farm that engages in the rearing of chickens and other birds) within the location. (IBID).

Technology play affects a poultry farmer in housing where faster growth and higher feed conversion ratio due to proper housing achieved and in order to increase productivity crossbreeding (using local and exotic varieties is done.

Integrate pest and disease management (PDM) for both crop production and livestock production (chicken, livestock) is also an important practice.

\section{Description of the site}

In this chapter, the research design, the target population, the sample size, the sampling population process, the data collection methods and instruments, the validity and reliability of the data and methods which will be used for data analysis will be discussed, ethical consideration and operationalization variables.

\section{Research design}

The study will adopt a descriptive design approach. This is because the objective will be to obtain some insights into the factors that determine poultry farming in the study area of Lusaka province in Zambia.

Secondly, the design is preferred because it is regarded as systematic. Thirdly, the design will contribute to a deeper insight and better understanding for the research problem an accurate and fair interpretation of results.

Lastly, the design will be flexible enough and therefore allow the respondents to raise issues with the researcher in relation to some questions and matters, which will be not be clear in the questionnaire or during the interview process. 


\section{Target population}

since the aim of the study is to determine the factors that influence poultry farmers in Lusaka province. Data required for determining the factors will be obtained from poultry farmers who are registered with the poultry association of Zambia in Lusaka province Zambia. Approximately 7000 registered members out of 30,000 potentials (PAZ 2017).

According to the case study one hundred and fifty (150) people will be targeted as sample of the study from four (4) selected villages within Shimabala in Kafue of Lusaka province. Although, the Poultry Association of Zambia has 7000 registered member and 30,000 potential farmers (PAZ 2017). Out of the targeted population, the researcher will prepare 100 structured questionnaires to support the focus group discussion.

\section{Description of the experiments done}

The researcher read articles, document that gave information about factors that affect poultry farmers and the factor that affect farms and also a document on sustainable development was reviewed.

The researcher is going to use the following data collection methods primary and secondary data.

\section{Secondary data collection}

Secondary data consists of information in relation to poultry farming obtained from journals, books, magazines, ministry of agriculture of Zambia publication, poultry association of Zambia, statistical abstracts, and economic surveys and from any other already documented information.

\section{Primary data collection}

Primary data, which is data collected from the source will solicited by means of research instruments such as questionnaires and interviews.

\section{Questionnaires}

Before embarking on the actual research, questionnaires will be constructed and a pilot study will be conducted in one of the nearest villages in Shimabala area, near to where the researcher stays to enable the researcher to test the validity and reliability of the research instruments to be used in the data collection exercise. Another reason for the pilot test is that it will enable the researcher to familiarize he/herself on what kind of feedback to get from the respondents and to make necessary adjustments to the research instruments where certain matters are not clear to the respondent.

\section{Description of the laboratory methods}

The methodology employed by the researcher in this paper, is by use of secondary data and observation. Research was done on internet from reliable sites and documents using simple random sampling methods.

The data collected will be analyzed using the qualitative and quantitative data analysis.

\section{Qualitative analysis}

Qualitative analysis takes the form of calculation of percentages, mean, range, standard deviations analysis of variance and covariance (ANOVA and ANACOVA), and presentation in the form of tables.

Quantitative analysis takes the form of multiple regression analysis to test the relationship between the independent variable (the output in terms of volume of sales in Kilograms produced) and the independent variables, inputs used (quantity of feeds, labour hours expended, quality of vaccines administered, quantity of energy used in terms of kilowatts). The relationship between output of the poultry farm and socioeconomic characteristics will be established by running regression analysis. The parameter estimates will reveal the extent of the relation of the dependent variable and the independent variables, inputs and the socio-economic characteristics. 
DOI: 10.21522/TIJMG.2015.SE.19.01.Art001

ISSN: $2520-310 \mathrm{X}$

\section{Description of the statistical methods used}

In analyzing the data, the researcher used the dependent variables to up with the independent variables.

\section{Description of the experiments done}

\section{Factor affecting poultry farmers}

There are many factors that have identified by the research. There are internal and external factors.

\section{Internal factors affecting a poultry farmer}

1. Facility for communication with the customer like getting information about the quality of the poultry product, packing information and many others

2. Leadership is managed by general management,

3. Relationship with customer is either good or bad.

4. Impact of import products.

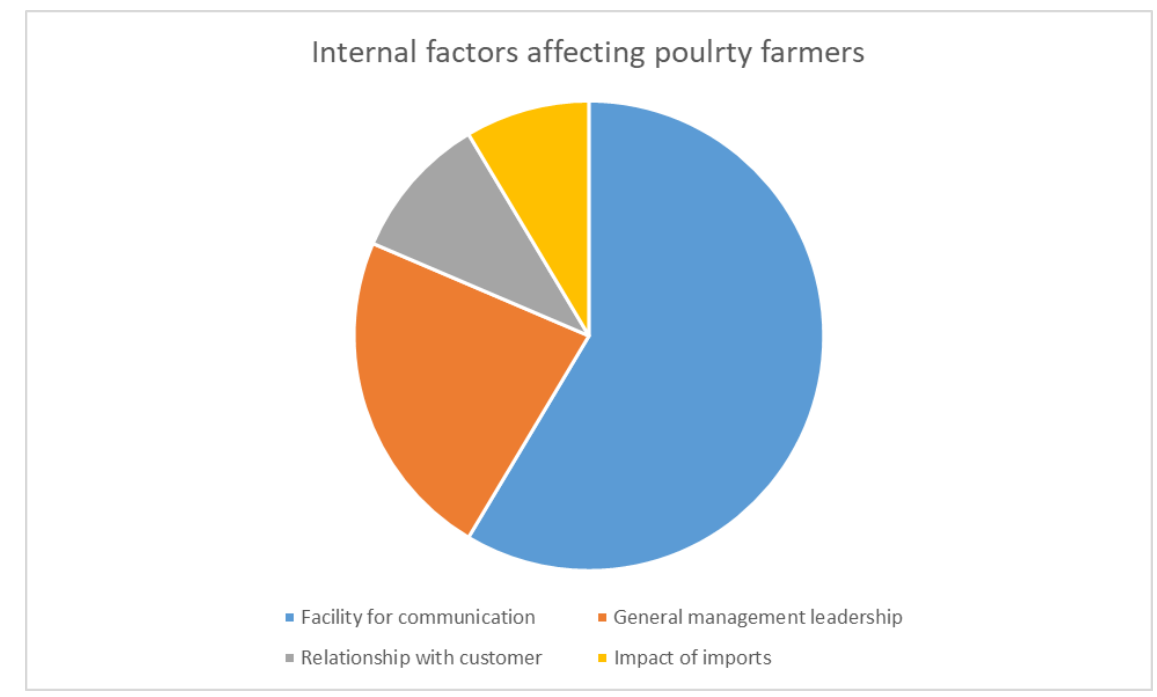

Figure 1. Internal factors affecting a poultry farmer

\section{External factors affecting a poultry farmer}

1. Service of the suppliers

2. Competitors

3. Customer bargaining

4. There is also a big threat of new entrant in the industry.

5. Huge impact of political, legal, and economic. social. Ethical and technological. 


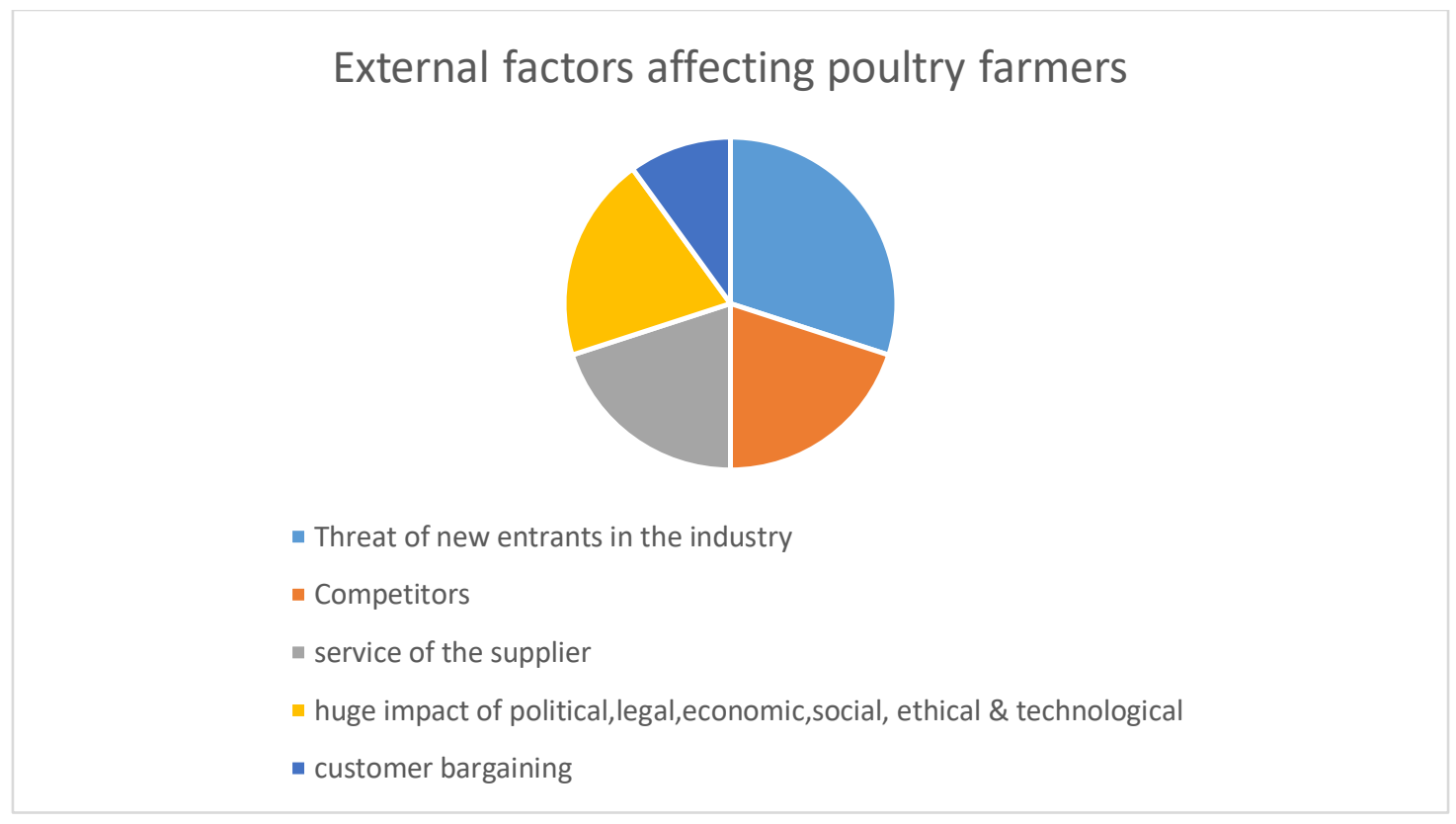

Figure 2. External factors affecting poultry farmers

\section{Factors affecting the farm}

Most of the poultry farms face a lot of problems due to the following factor:

1. Lack of strategic management plan

2. Lack of vision and mission

3. Lack of total quality management

4. Lack of product innovation

5. Lack of operation and service efficiency.

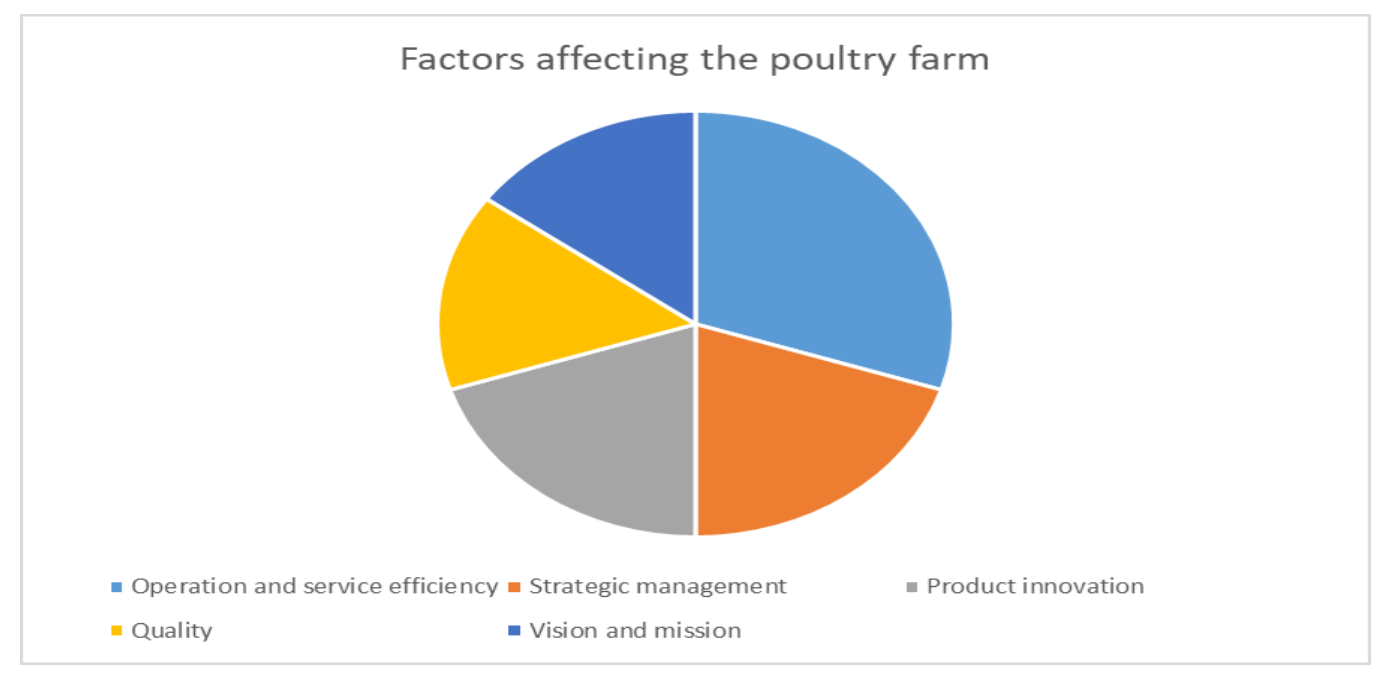

Figure 3. Factors affecting the poultry farm 
DOI: 10.21522/TIJMG.2015.SE.19.01.Art001

ISSN: 2520-310X

Table 1. Summary of the Factors

\begin{tabular}{|l|l|l|}
\hline $\begin{array}{l}\text { Internal factors affecting poultry } \\
\text { farmers }\end{array}$ & $\begin{array}{l}\text { External factors affecting } \\
\text { poultry farmers }\end{array}$ & $\begin{array}{l}\text { Factors affecting the poultry } \\
\text { farm }\end{array}$ \\
\hline $\begin{array}{l}\text { Lack of facilities for } \\
\text { communication with the customer } \\
\text { like getting information about the } \\
\text { quality of the product, packing } \\
\text { information. }\end{array}$ & Service of the supplier & $\begin{array}{l}\text { Lack of strategic management } \\
\text { plan }\end{array}$ \\
\hline $\begin{array}{l}\text { Leadership is managed by the } \\
\text { general management }\end{array}$ & Competitors & Lack of vision and mission \\
\hline $\begin{array}{l}\text { Lack of good relationship with the } \\
\text { customers. }\end{array}$ & $\begin{array}{l}\text { Threat of new entrant in } \\
\text { the industry. }\end{array}$ & $\begin{array}{l}\text { Lack of total quality } \\
\text { management }\end{array}$ \\
\hline $\begin{array}{l}\text { Impact of import products on the } \\
\text { market. }\end{array}$ & Customer bargaining & $\begin{array}{l}\text { Lack of operational and } \\
\text { service efficiency }\end{array}$ \\
\hline & $\begin{array}{l}\text { Huge impact of political, } \\
\text { legal, economic, social, } \\
\text { ethical and technological }\end{array}$ & \\
\hline
\end{tabular}

\section{Discussions}

The study has shown that there a lot of factors affecting both the farmer and farm. The external factor is more pressing on the farmer than the internal factors. The internal factors such as lack of training can be easily managed by the farmer unlike the external factors which are beyond their reach. While the factors affecting the farm, some can be managed by the farmer while some cannot.

\section{Conclusion}

In conclusion, factors affecting poultry farmers and farms may be a lot but there are other factors factors that need to take care of, hence the need for a further research and theories in order for the poultry industry to be sustained in Zambia. The researcher recommends a further research to come with theories that will help to sustain the industry so that the generations to come will benefit.

\section{Reference}

[1].Abhishek, Singh (2017) What is Nation Integration. Greater Noida Institute of Technology.

[2].Amini M, Ramezani M (2006) Evaluation of Factors in the Success of Cooperative Companies Poultry Meat, Tehran Province, Agriculture and Development Economics, year XIV, NO55Evaluation of Factors in the Success of Cooperate Companies Poultry Meat, Tehran, Province, Agricultural and Development Economics, Year XIV. 2016

[3].GRZ (2011) Sixth National Development Plan (SNDP_2011-2015) Sustained Economic Growth and Poverty Reduction- Ministry of Finance, Lusaka-Zambia.

[4].Mulenga Davis (2016) Zambian Poultry Farmers ask Government to protect industry from cheap Imports.

[5].Mupenseni Kennedy (2015) Animal Feed Production-Lochamp, 20 years Experience.www.time.co.zm.

[6].Mbale Tryness (2018) High Feed Price to Injure Poultry Sector.

[7].Poultry Farming/poultry, Fisheries and wildlife Sciences

[8].https://www.omicsonline.org/poultry-farming-peer-reviewed-open-access-journal.phd. 


\section{Texila International Journal of Management}

Special Edition Apr 2019

[9]. https://images.agri-profocus.nl/upload/post/PAZ_Presentation_at_the_Doing_busines_forum-Poultry_26th_APRIL_2017-11498460804.pdf

[10]. Poultry Association of Zambia (2017) Presentation on Doing Business in the Poultry Industry Southern Sun. 